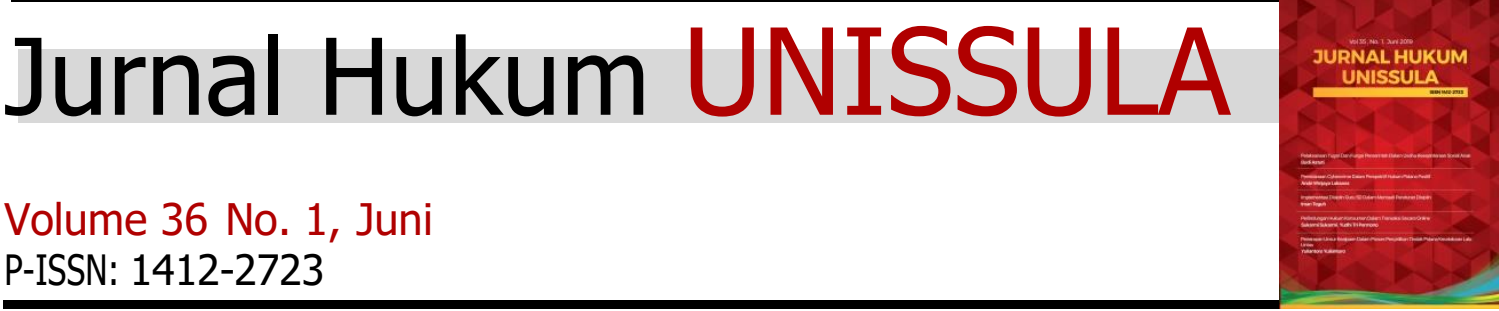

This work is licensed under a Creative Commons Attribution 3.0 International Licens

\section{ANALISIS YURIDIS MEKANISME PEMAKZULAN PRESIDEN DAN WAKIL PRESIDEN MENURUT UUD NEGARA REPUBLIK INDONESIA TAHUN 1945 (SETELAH PERUBAHAN)}

\section{Zainal Arifin}

Lembaga Bantuan Hukum (LBH), Indonesia. E-mail: zainalarifinjurnal@gmail.com

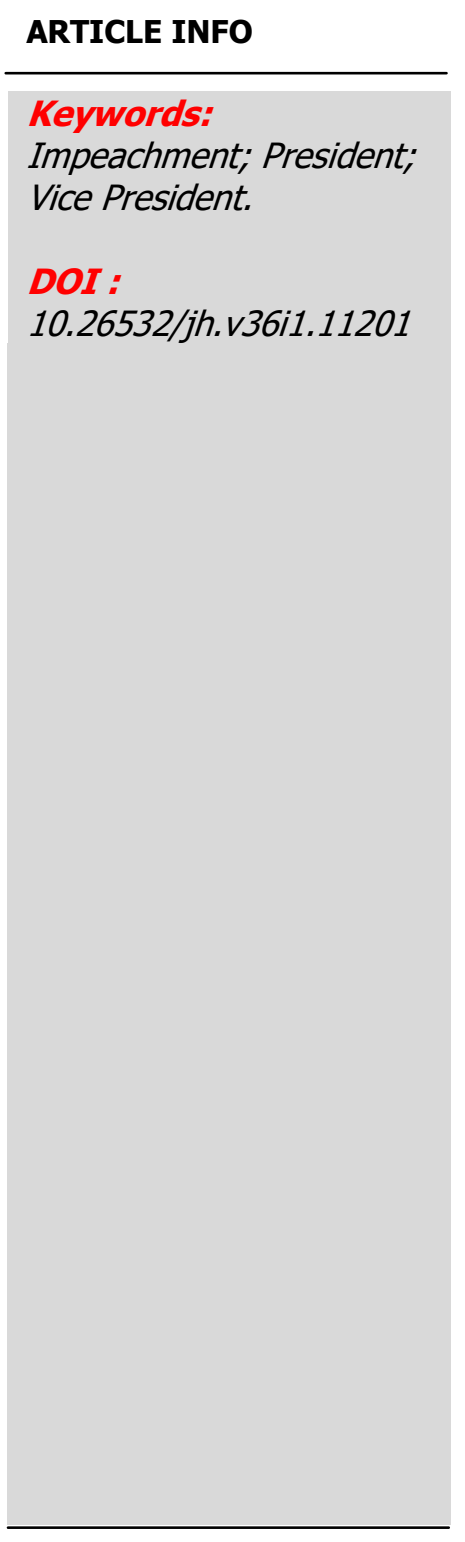

\begin{abstract}
The term impeachment is not explicitly written in the constitution. In Big Indonesian Dictionary New Edition deposed mentioned is put positions; king abdicated. Prof. Jimly Asshiddiqie explained, impeachment is the uptake of the Arabic language which means derived from office. Or equal to the term 'impeachment' in the constitution of Western countries. Dismissal of the President and / or Vice President of the mechanism is already provided for in Article $7 A$ and $7 B$ 1945. Prior to MPR dismiss both the President and / or Vice President, the mechanisms that must be taken is the first, the proposed dismissal of the President and / or Vicepresident of the Board House of Representatives to the Assembly with only first submit a request to the Constitutional Court to examine, and decide upon the opinion of the House that the President and / or Vice President has violated the law in the form of treason against the State, corruption, bribery , criminal acts other heavy, or moral turpitude; and / or opinions that the president and / or vice president is no longer eligible as president and / or vice president.
\end{abstract}

Istilah pemakzulan tidak tertulis eksplisit dalam konstitusi. Dalam Kamus Besar Bahasa Indonesia Edisi Baru disebutkan makzul adalah meletakan jabatan; turun tahta raja. Prof. Jimly Asshiddiqie menjelaskan, pemakzulan adalah bahasa serapan dari bahasa Arab yang berarti diturunkan dari jabatan. Atau sama dengan istilah 'impeachment' dalam konstitusi negara-negara Barat. Pemberhentian Presiden dan/atau Wakil Presiden mekanismenya sudah diatur di dalam Pasal 7A dan 7B UUD 1945. Sebelum MPR memberhentikan baik itu Presiden dan/atau Wapres, mekanisme yang harus ditempuh terlebih dahulu adalah, usul pemberhentian Presiden dan/atau Wakil presiden tersebut diajukan oleh Dewan Perwakilan Rakyat (DPR) kepada MPR dengan hanya terlebih dahulu mengajukan permintaan kepada Mahkamah Konstitusi (MK) untuk memeriksa, mengadili, dan memutus pendapat DPR bahwa Presiden dan/atau Wakil Presiden telah melakukan pelanggaran hukum berupa pengkhianatan terhadap Negara, korupsi, penyuapan, tindak pidana berat lainnya, atau perbuatan tercela; dan/atau pendapat bahwa Presiden dan/atau wakil presiden tidak lagi memenuhi syarat sebagai presiden dan/atau wakil presiden.

Copyright (C) 2020 JURNAL HUKUM UNISSULA. All rights reserved. 


\section{A. PENDAHULUAN}

Amat menarik mencermati perkembangan kasus Bank Century pasca terbentuknya Pansus Hak Angket DPR. Bagaimana tidak, selain multi dimensional, perkembangan isunya sudah memasuki wilayah yang sangat krusial dalam bidang ketatanegaraan. Hal ini dikarenakan Pansus DPR kasus Bank Century juga memeriksa pihak-pihak terkait termasuk mantan Gubernur Bank Indonesia saat itu yang juga Wakil Presiden (wapres) saat ini dan Menteri Keuangan (Menkeu). Isu ini bergulir ke tahap yang lebih tinggi yaitu usul penonaktifan Wakil Presiden. ${ }^{1}$

Keberadaan hak angket DPR diatur dalam Pasal 20A ayat (2) UUD 1945 dan kemudian ditegaskan kembali dalam Pasal 27 UU Nomor 22 Tahun 2003 tentang Susunan dan Kedudukan MPR, DPR, DPD dan DPRD dan Pasal 176-183 Peraturan Tata tertib DPR. Walaupun Pasal 20A ayat (4) UUD 1945 menegaskan bahwa ketentuan lebih lanjut mengenai hak DPR itu akan diatur dalam undang-undang, namun UU Nomor 22 Tahun 2003 tidak mengatur secara rinci tentang pelaksanaan dari hak angket itu.

Undang-undang yang mengatur penggunaan hak angket ialah UU Nomor 6 Tahun 1954 tentang Hak Angket Dewan Perwakilan Rakyat. UU ini berasal dari zaman sistem pemerintahan parlementer di bawah UUD Sementara Tahun 1950, namun sampai sekarang belum pernah dicabut. Mahkamah Konstitusi melalui putusannya tanggal 26 Maret 2004 telah menegaskan bahwa Undang-Undang Nomor 6 Tahun 1954 itu masih berlaku berdasarkan ketentuan Pasal I Aturan Peralihan UUD 1945. Dengan demikian, tidak ada keraguan apapun untuk menggunakan ketentuanketentuan dalam UU Nomor 6 Tahun 1954 itu untuk melaksanakan hak angket DPR. Penerapannya tentu harus mempertimbangkan sistem pemerintahan presidensial yang kini berlaku di bawah UUD $1945 .^{2}$

Dari segi ketatanegaraan, hal ini amat penting untuk dicermati karena isu itu kemudian menimbulkan beragam perbedaan pendapat dimasyarakat dan juga di kalangan para pejabat negara terkait penonaktifan Wapres tersebut. Pihak yang berpendapat perlunya penonaktifan Wakil Presiden ini antara lain disampaikan oleh pengamat hukum tata negara Irman Putra Sidin, menurutnya sebagai pembantu Presiden, Wakil Presiden dapat dinonaktifkan oleh Presiden selaku pemegang kekuasaan pemerintahan. Seperti tercantum dalam pasal 4 ayat (1) UUD 1945, Presiden Republik Indonesia memegang kekuasaan pemerintahan menurut Undang-Undang Dasar. Kemudian, dalam ayat (2) disebutkan, dalam melakukan kewajibannya Presiden dibantu oleh satu orang Wakil Presiden. Menurutnya yang tidak bisa dinonaktifkan adalah Presiden, karena dia pemegang kekuasaan pemerintahan yang tugasnya langsung diberikan konstitusi. ${ }^{3}$

\footnotetext{
1 Dinoroy Aritonang, SH., Mencermati Penonaktifan Wapres dan Menkeu, http://www.sinarharapan.co.id/cetak/berita/read/mencermati-penonaktifan-wapres-dan-menkeu, 20 Januari 2010

2 Yusril Ihza Mahendra, Angket DPR: Mungkinkah Mengimpeach Presiden?, http://yusril.ihzamahendra.com /2008/06/29/sekitar-hak-angket-dpr-tentang-bbm, 29 June 2008.

3 Pengamat : Wapres Bisa di Non Aktifkan. http://suaramerdeka.com.
} 
Sedangkan diantara anggota pansus, yang paling gencar menyarankan agar Wapres dan Menkeu menonaktifkan diri selama pemeriksaan adalah Bambang Soesetyo yang berasal dari Golkar. Nampak adanya serangan sistematis dari kubu Golkar terhadap kedua pejabat pemerintah tadi. Yang agak kurang pas adalah membandingkan keduanya dengan Susno dan AH Ritonga pada kasus Bibit-Chandra. Entah cara berfikir pansus seperti apa, membandingkan Wapres sebagai orang kedua di negara ini serta seorang menteri dengan levelering jabatan yang jauh beberapa tingkat dibawahnya. Yang anehnya kemudian pansus secara aklamasi mengeluarkan juga imbauan tersebut. Sangat disayangkan para anggota pansus kurang menghargai arti dari pansus sebagai sebuah hak dan peran wakil rakyat yang semestinya diletakkan tinggi dengan kewibawaan yang terjaga. Tidak terlalu mudah membuat imbauan yang kelasnya kurang. ${ }^{4}$

Sementara itu, pendapat yang berbeda terkait penonaktifan Wakil Presiden ini antara lain disampaikan oleh Presiden RI sendiri, Presiden Susilo Bambang Yudhoyono menyatakan Wakil Presiden Boediono dan Menteri Keuangan Sri Mulyani Indrawati tidak perlu nonaktif atau mengundurkan diri selama Panitia Angket DPR RI untuk Bank Century bekerja atau bahkan mengundurkan diri karena berdasarkan Pasal 7 UUD 1945 tidak ada pemberhentian sementara Presiden dan Wakil Presiden ${ }^{5}$. Lebih lanjut Presiden Susilo Bambang Yudhoyono menegaskan bahwa impeachment harus mengacu kepada UUD 1945. Presiden juga mengingatkan bahwa sistem presidensil tidak menganut mosi tidak percaya. Jika hal itu terjadi, kabinet akan jatuh bangun dan menteri berguguran. ${ }^{6}$

Wacana yang berkembang terkait kasus Bank Century ini tidak hanya berhenti pada isu penonaktifan saja, tapi lebih jauh berkembang menjadi isu pemakzulan terhadap Wakil Presiden Boediono karena diduga sebagai pihak yang bertanggungjawab dalam kasus penanganan Bank Century yang menggunakan keuangan negara sebesar 6,7 triliun rupiah. Isu tentang pemakzulan Wakil Presiden ini pun kemudian mendapat tanggapan yang beragam di masyarakat. Wakil Ketua DPR Anis Matta di DPR menilai pemakzulan terhadap Presiden SBY dan Wapres Boediono tetap dimungkinkan jika mereka terbukti bersalah terkait skandal Bank Century. Untuk memakzulkan presiden atau wapres, pansus dapat menempuh 2 jalur yaitu politik dan hukum. Di jalur hukum, kasus ini bisa dibawa ke KPK jika Pansus memutuskan ada pidana. Dalam kasus Century peluang pemakzulan ada asalkan syarat terbukti, misalkan pidana. Dan bila KPK mempunyai keputusan, maka keputusan mempunyai dampak ke pemakzulan. ${ }^{7}$

4 Prayitno Ramelan, Antara Pansus, Wapres Boediono dan Menkeu Sri Mulyani, http://polhukam.kompasiana.com/ 2009/12/19/ antara-pansus-wapres-boediono-dan-menkeu-srimulyani, 19 Desember 2009.

5 Presiden : Wapres dan Menkeu Tidak Perlu Nonaktif. arsipberita.com/.../presiden-wapres-dan-menkeutidak-perlu-nonaktif, 20 Desember 2009.

6 SBY: Impeachment Harus Mengacu UUD 1945, www.republika.co.id/berita/101848/ sby_kita_tak_menganut_mosi_tidak_percaya, Kamis, 21 Januari 2010.

7 Pemakzulan Presiden dan Wapres Dimungkinkan, http://www.detiknews.com/read/pemakzulanpresiden-dan-wapres-dimungkinkan, Rabu, 27/01/2010. 
Ketua MK Mahfud MD menjelaskan, kehati-hatian pengaturan soal pemakzulan ini didasarkan pada alasan agar DPR tidak mudah dan semenamena menjatuhkan presiden. Setiap proses pemakzulan harus melalui prosedur dan proses yang tidak mudah dan berliku. Semangat UUD 1945 mengatur soal pemakzulan itu agar tidak digunakan semaunya sendiri oleh yang berkepentingan. Makanya dibikin panjang dan berliku. ${ }^{8}$

Sementara itu pendapat yang berbeda disampaikan Menteri Hukum dan Hak Asasi Manusia Patrialis Akbar mengatakan, tidak ada celah hukum bagi pemakzulan presiden dan wakil presiden karena konstitusi sudah mengatur secara ketat perihal itu. Banyak persyaratan yang dipersyaratkan konstitusi, dan itu satu pun tidak terpenuhi dalam kasus Bank Century ini. Persyaratan pertama, dalam UUD, prinsip dasarnya dalam sistem presidensial, presiden itu tak bisa dijatuhkan di tengah jalan, karena dia dipilih melalui pemilihan umum. Prinsip kedua, "fix term" lima tahun masa jabatan dijamin, ini tidak boleh diganggu dengan alasan politik. Dan yang ketiga, presiden adalah sebagai lambang negara, bahkan dalam NKRI presiden lambang negara kesatuan, jadi tak hanya sebagai kepala pemerintahan, tapi lambang negara. ${ }^{9}$

Ketua DPD RI Irman Gusman mengatakan pemakzulan masih jauh dari proses apa yang berkembang di Panitia Khusus Angket DPR tentang kasus Bank Century. Menurut DPD, persoalan kasus Century merupakan sisi pembuktian pelanggaran hukum, bukan upaya untuk memakzulkan Presiden dan atau Wakil Presiden. ${ }^{10}$

Berdasarkan atas wacana beragam yang berkembang tersebutlah, maka dalam penulisan makalah ini pemakalah akan menganilisis lebih jauh dai perspektif hukum, bagaimanakah sebenarnya mekanisme pemakzulan Presiden dan Wakil Presiden di Indonesia.

\section{B. METODE PENELITIAN}

Berdasarkan tujuan penelitian di atas, metode pendekatan pada penelitian ini adalah metode pendekatan yuridis sosiologis, dengan pertimbangan permasalahan yang diteliti adalah mengenai hubungan aspek sosial pendidikan terhadap faktor yuridis. ${ }^{11}$ Pendekatan yuridis sosiologis merupakan suatu pendekatan penelitian terhadap efektifitas hukum, maka relevansinya hukum tidak dikonsesikan sebagai suatu gejala normatif yang otonom, tetapi suatu institusi sosial yang secara riil berkaitan dengan variabel-variabel sosial. Secara eksplisit dapat diperjelas bahwa metode pendekatan sosiologis merupakan penelitian yang melihat dan menganalisis tentang bekerjanya hukum dalam tataran kenyataan. $^{12}$

8 Mekanisme dan Prosedur Panjang Pemakzulan Presiden dan Wapres,

http://holistikasaya.wordpress.com/2010/01/31/mekanisme-dan-prosedur-panjang-pemakzulanpresiden-dan-wapres/

9 Tak Ada Celah Pemakzulan Presiden dan Wapres, www.republika.co.id/ menkumham_tak_ada_celah_pamkzulan_presiden_dan_wapres, Selasa, 02 February 2010.

10 Skandal Bank Century: Pemakzulan Presiden Masih Jauh, http://www.mediaindonesia.com/read/ Pemakzulan-Presiden-Masih-Jauh, Sabtu, 23 Januari 2010.

11 Lexy J. Moleong. 2000. Metodologi Penelitian Hukum. Citra Aditya Bakti. Bandung. hlm. 11.

12 Soerjono Soekanto, Pengantar Penelitian Hukum, Universitas Indonesia Pers, Jakarta, 1984, hal. 51 


\section{HASIL PENELITIAN DAN PEMBAHASAN}

\section{Pemakzulan Presiden dan Wakil Presiden}

Istilah pemakzulan tidak tertulis dalam konstitusi UUD 1945. Pasal 7A perubahan ketiga UUD 1945 hanya menyebut, Presiden dan atau Wakil Presiden dapat diberhentikan dalam masa jabatannya oleh MPR atas usul DPR, baik apabila terbukti telah melakukan pelanggaran hukum berupa pengkhianatan terhadap negara, korupsi, penyuapan, tindak pidana berat lainnya, atau perbuatan tercela maupun apabila terbukti tidak lagi memenuhi syarat sebagai Presiden dan atau Wakil Presiden.

Istilah pemakzulan tidak tertulis eksplisit dalam konstitusi. Dalam Kamus Besar Bahasa Indonesia Edisi Baru disebutkan makzul adalah meletakan jabatan; turun tahta raja. Lantas dari mana istilah itu muncul? Mantan Ketua Mahkamah Konstitusi (MK) Jimly Asshiddiqie menjelaskan, pemakzulan adalah bahasa serapan dari bahasa Arab yang berarti diturunkan dari jabatan. Atau sama dengan istilah 'impeachment' dalam konstitusi negara-negara Barat.

Impeachment itu sendiri adalah tindakan menuntut pertanggungjawaban dalam rangka pengawasan parlemen kepada presiden, apabila presiden melanggar hukum. Mekanisme pemakzulan diatur dalam konstitusi agar forum politik DPR tidak bisa serta merta menjatuhkan Presiden dan atau Wapres. Sebagaimana Presiden tidak bisa membubarkan DPR, DPR juga tidak bisa menjatuhkan Presiden dan atau Wapres kecuali Presiden dan atau Wapres terbukti melakukan pelanggaran hukum ${ }^{13}$.

\section{Mekanisme pemakzulan Presiden dan Wakil Presiden}

Wacana Pemakzulan Presiden dan Wakil Presiden terus bergulir menyusul kerja-kerja Pansus Bank Century yang belakangan ini mengarah pada pemakzulan. Pemakzulan presiden dan atau wakil presiden memang dimungkinkan dalam UUD 1945 hasil amendemen. Tetapi agar pemakzulan tidak dijadikan bahan mainan, UUD 1945 mengatur secara detail dan hati-hati ${ }^{14}$. Dan berikut adalah mekanisme pemakzulan Presiden dan Wakil Presiden.

a. Mekanisme pemakzulan Presiden dan Wakil Presiden menurut UUD Negara Republik Indonesia Tahun 1945

Mekanisme pemakzulan diatur dalam UUD 1945 dan aturanaturan lain yang terkait, ketentuan dan mekanisme pemakzulan tersebut antara lain adalah sebagai berikut:

1)Pasal 7A perubahan ketiga UUD 1945

Presiden dan/atau Wakil Presiden dapat diberhentikan dalam masa jabatannya oleh Majelis Permusyawaratan Rakyat atas usul Dewan Perwakilan Rakyat, baik apabila terbukti telah

13 Pemakzulan tidak dikenal dalam konstitusi, http://www.waspada.co.id/index, 26 January 2010.

14 Mekanisme dan Prosedur Panjang Pemakzulan Presiden dan Wapres,

http://holistikasaya.wordpress.com/2010/01/31/mekanisme-dan-prosedur-panjang-pemakzulanpresiden-dan-wapres. 
melakukan pelanggaran hukum berupa pengkhianatan terhadap negara, korupsi, penyuapan, tindak pidana berat lainnya, atau perbuatan tercela maupun apabila terbukti tidak lagi memenuhi syarat sebagai Presiden dan/atau Wakil Presiden.

2)Pasal 7B perubahan ketiga UUD 1945

Usul pemberhentian Presiden dan/atau Wakil Presiden dapat diajukan oleh Dewan Perwakilan Rakyat kepada Majelis Permusyawaratan Rakyat hanya dengan terlebih dahulu mengajukan permintaan kepada Mahkamah Konstitusi untuk memeriksa, mengadili, dan memutus pendapat Dewan Perwakilan Rakyat bahwa Presiden dan/atau Wakil Presiden telah melakukan pelanggaran hukum berupa pengkhianatan terhadap negara, korupsi, penyuapan, tindak pidana berat lainnya, atau perbuatan tercela; dan/atau pendapat bahwa Presiden dan/atau Wakil Presiden tidak lagi memenuhi syarat sebagai Presiden dan/atau Wakil Presiden.

Pendapat Dewan Perwakilan Rakyat bahwa Presiden dan/atau Wakil Presiden telah melakukan pelanggaran hukum tersebut ataupun telah tidak lagi memenuhi syarat sebagai Presiden dan/atau Wakil Presiden adalah dalam rangka pelaksanaan fungsi pengawasan Dewan Perwakilan Rakyat.

Pengajuan permintaan Dewan Perwakilan Rakyat kepada Mahkamah Konstitusi hanya dapat dilakukan dengan dukungan sekurangkurangnya 2/3 dari jumlah anggota Dewan Perwakilan Rakyat yang hadir dalam sidang paripurna yang dihadiri oleh sekurangkurangnya 2/3 dari jumlah anggota Dewan Perwakilan Rakyat.

Mahkamah Konstitusi wajib memeriksa, mengadili, dan memutus dengan seadiladilnya terhadap pendapat Dewan Perwakilan Rakyat tersebut paling lama sembilan puluh hari setelah permintaan Dewan Perwakilan Rakyat itu diterima oleh Mahkamah Konstitusi.

Apabila Mahkamah Konstitusi memutuskan bahwa Presiden dan/atau Wakil Presiden terbukti melakukan pelanggaran hukum berupa pengkhianatan terhadap negara, korupsi, penyuapan, tindak pidana berat lainnya, atau perbuatan tercela; dan/atau terbukti bahwa Presiden dan/atau Wakil Presiden tidak lagi memenuhi syarat sebagai Presiden dan/atau Wakil Presiden, Dewan Perwakilan Rakyat menyelenggarakan sidang paripurna untuk meneruskan usul pemberhentian Presiden dan/atau Wakil Presiden kepada Majelis Permusyawaratan Rakyat.

Majelis Permusyawaratan Rakyat wajib menyelenggarakan sidang untuk memutuskan usul Dewan Perwakilan Rakyat tersebut paling lambat tiga puluh hari sejak Majelis Permusyawaratan Rakyat menerima usul tersebut.

Keputusan Majelis Permusyawaratan Rakyat atas usul pemberhentian Presiden dan/atau Wakil Presiden harus diambil 
dalam rapat paripurna Majelis Permusyawaratan Rakyat yang dihadiri oleh sekurangkurangnya 3/4 dari jumlah anggota dan disetujui oleh sekurangkurangnya $2 / 3$ dari jumlah anggota yang hadir, setelah Presiden dan/atau Wakil Presiden diberi kesempatan menyampaikan penjelasan dalam rapat paripurna Majelis Permusyawaratan Rakyat.

3)Pemakzulan Presiden dan Wakil Presiden sekaligus

Pasal 8 ayat (1) perubahan ketiga UUD 1945 menyebutkan, jika Presiden mangkat, berhenti, diberhentikan, atau tidak dapat melakukan kewajibannya dalam masa jabatannya, ia digantikan oleh Wakil Presiden sampai habis masa jabatannya. Dengan kata lain, Wapres otomatis menduduki jabatan Presiden sebagai kepala negara dan pemerintahan.

Sebagai seorang presiden, 'wapres lama' bisa memilih wakilnya lewat mekanisme yang diatur dalam Pasal 8 ayat (2) perubahan ketiga UUD 1945. Pasal tersebut berbunyi, dalam hal terjadi kekosongan Wakil Presiden, selambat-lambatnya dalam waktu enam puluh hari, Majelis Permusyawaratan Rakyat menyelenggarakan sidang untuk memilih Wakil Presiden dari dua calon yang diusulkan oleh Presiden. Proses yang sama juga dilakukan jika yang dicopot adalah Wakil Presiden.

Pasal 8 ayat (3) perubahan ketiga UUD 1945 menyebutkan, jika Presiden dan Wakil Presiden mangkat, berhenti, diberhentikan, atau tidak dapat melakukan kewajibannya dalam masa jabatannya secara bersamaan, pelaksana tugas kepresidenan adalah Menteri Luar Negeri, Menteri Dalam Negeri, dan Menteri Pertahanan secara bersama-sama. Selambatlambatnya tiga puluh hari setelah itu, Majelis Permusyawaratan Rakyat menyelenggarakan sidang untuk memilih Presiden dan Wakil Presiden dari dua pasangan calon Presiden dan Wakil Presiden yang diusulkan oleh partai politik atau gabungan partai politik yang pasangan calon Presiden dan Wakil Presidennya meraih suara terbanyak pertama dan kedua dalam pemilihan umum sebelumnya, sampai berakhir masa jabatannya. Menteri luar negeri, Mendagri dan Menhan itu triumvirat yang menjalankan pemerintahan sebelum pemerintahan baru terbentuk. Dalam konteks politik sekarang.

4)Peraturan MK Nomor 21 Tahun 2009

Terdapat tiga jenis amar putusan Mahkamah Konstitusi yang bisa dihasilkan melalui proses persidangan mengenai permohonan penilaian dugaan pelanggaran Presiden dan/atau Wakil Presiden yang diajukan DPR terkait dengan proses pemakzulan. Berdasarkan salinan Peraturan MK Nomor 21 Tahun 2009, tiga jenis amar putusan tersebut antara lain adalah :

Pertama, permohonan tidak dapat diterima karena tidak memenuhi kelengkapan seperti tercantum dalam Tata Cara Mengajukan Permohonan. 
Kedua, MK membenarkan pendapat DPR bahwa Presiden dan/atau Wakil Presiden terbukti melakukan pelanggaran hukum berupa pengkhianatan terhadap negara, korupsi, penyuapan, tindak pidana berat lainnya, atau perbuatan tercela.

Ketiga, Permohonan ditolak MK apabila pendapat DPR terkait dugaan pelanggaran yang dilakukan Presiden dan/atau Wakil Presiden tidak terbukti.

Dalam Peraturan Mahkamah Konstitusi Nomor 21 Tahun 2009 juga disebutkan bahwa putusan Mahkamah Konstitusi bersifat final secara yuridis dan mengikat bagi DPR selaku pihak yang mengajukan permohonan. Sedangkan dalam Bab Ketentuan Lain-Lain disebutkan, putusan Mahkamah Konstitusi yang mengabulkan permohonan DPR tidak menutup kemungkinan diajukannya Presiden dan/atau Wakil Presiden dalam persidangan pidana, perdata, dan/atau tata usaha negara sesuai dengan asas dan hukum acara masing-masing.

Dari ketentuan tersebut dapat dipahami bahwa UUD 1945 telah menentukan lembaga DPR memiliki tiga fungsi, yaitu fungsi legislasi, fungsi anggaran dan fungsi pengawasan. Diantara fungsi badan legislatif yang paling penting adalah menentukan kebijakan dengan membuat undang-undang, serta mengontrol/mengawasi badan eksekutif sesuai dengan kebijakan-kebijakan yang telah ditetapkan. Untuk melaksanakan fungsi ini, DPR diberikan hak yang berkaitan dengan kontrol (pengawasan) seperti Hak Bertanya, Hak Interpelasi, Hak Angket, serta Mosi di sistem parlementer ${ }^{15}$. Dan atas dasar pelaksanaan fungsi pengawasan ini maka DPR dapat mengajukan usul pemberhentian Presiden dan/atau Wakil Presiden sebagaimana diatur dalam Pasal 7B ayat (2) UUD 1945 di atas.

Proses fungsi pengawasan dari DPR dalam rangka usul pemberhentian Presiden dan/atau Wakil Presiden ini dimulai dari hak menyatakan pendapat yang dimiliki oleh setiap anggota DPR. Mekanisme pengajuan hak menyatakan pendapat ini diatur dalam pasal 182 sampai dengan pasal 188 Peraturan Tata Tertib DPR (Keputusan DPR nomor 15/DPR RI/I/2004-2005). Pertama-tama, minimal harus ada 17 (tujuh belas) orang anggota DPR yang mengajukan usul menyatakan pendapat mengenai dugaan bahwa Presiden dan/atau Wakil Presiden melakukan pelanggaran hukum berupa pengkhianatan terhadap negara, korupsi, penyuapan, tindak pidana berat lainnya atau perbuatan tercela maupun tidak lagi memenuhi syarat sebagai Presiden dan/atau Wakil Presiden. Usul menyatakan pendapat beserta penjelasannya tersebut disampaikan secara tertulis kepada Pimpinan DPR dengan disertai daftar nama dan tanda tangan pengusul serta nama Fraksinya. Pimpinan DPR memberitahukan kepada Anggota masuknya usul menyatakan pendapat pada Rapat Paripurna, kemudian usul tersebut dibagikan kepada seluruh Anggota. 
Setelah pemberitahuan Pimpinan DPR dalam Rapat Paripurna, Usulan tersebut dibahas dalam Rapat Badan Musyawarah untuk menentukan waktu dan agenda Rapat Paripurna berikutnya. Dalam Rapat Badan Musyawarah yang membahas penentuan waktu pembicaraan dalam Rapat Paripurna tentang usul menyatakan pendapat tersebut, kepada pengusul diberikan kesempatan untuk memberikan penjelasan tentang usulnya secara ringkas. Dalam Rapat Paripurna yang telah ditentukan agendanya pada Rapat Badan Musyawarah, anggota yang mengusulkan pendapat atas tuntutan impeachment kepada Presiden dan/atau wakil Presiden diberikan kesempatan untuk memberikan penjelasan atas usulnya. FraksiFraksi diberikan kesempatan untuk menyampaikan pandangannya atas usulan tersebut. Kemudian, kepada anggota yang mengusulkan pendapat tuntutan impeachment diberikan hak untuk menjawab pandangan fraksi itu.

Selanjutnya, Rapat Paripurna memutuskan apakah usulan hak menyatakan pendapat tersebut secara prinsip dapat diterima atau tidak. Bilamana Rapat Paripurna memutuskan untuk menolak usulan hak menyatakan pendapat maka usulan tersebut tidak dapat diajukan kembali pada Masa Sidang itu. Namun bila Rapat Paripurna menyetujui usulan hak menyatakan pendapat, DPR kemudian membentuk Panitia Khusus. Tugas Panitia Khusus adalah melakukan pembahasan dengan Presiden dan atau Wakil Presiden. Dalam melakukan pembahasan atas tuduhan impeachment kehadiran Presiden dan/atau Wakil Presiden tidak dapat diwakili. Hal ini berkaitan dengan hak subpoena yang dimiliki oleh Panitia Khusus dalam rangka hak angket atau hak menyatakan pendapat.

Hak subpoena adalah memanggil secara paksa seseorang yang dirasakan perlu didengar keterangannya pada penyelidikan yang dilakukan panitia khusus. Bilamana yang bersangkutan tidak hadir dalam pemanggilan yang dilakukan oleh Panitia Khusus maka ada ancaman sandera selama 15 (lima belas) hari. Pengaturan ini adalah aturan lebih lanjut dari ketentuan pasal 30 UU Nomor 22 Tahun 2003 tentang Susunan dan Kedudukan MPR, DPR, DPD dan DPRD. Meskipun pelanggaran hukum yang dilakukan oleh Presiden dan/atau Wakil Presiden namun proses penyelidikan yang dilakukan oleh DPR adalah dalam konteks fungsi pengawasan dan hak menyatakan pendapat yang diatur dalam peraturan tata tertib DPR. Sehingga proses penyelidikan yang dilakukan DPR bukanlah dalam arti sedang menyelidiki perkara pidana sebagaimana yang dilakukan oleh penyelidik, penyidik atau penuntut umum.

Proses penyelidikan pelanggaran hukum oleh Presiden dan/atau Wakil Presiden oleh DPR harus sesuai dengan mekanisme yang telah diatur dalam peraturan tata tertibnya. Selain itu Panitia Khusus dalam melakukan pembahasan juga dapat mengadakan Rapat Kerja, Rapat Dengar Pendapat, dan/atau Rapat Dengar Pendapat Umum dengan pihak yang dipandang perlu, termasuk 
dengan pengusul. Pembahasan yang dilakukan oleh Panitia Khusus menjadi bahan pengambilan keputusan dalam Rapat Paripurna untuk menyetujui atau menolak pernyataan pendapat tersebut.

Pengambilan keputusan dalam hal tuduhan impeachment kepada Presiden dan/atau Wakil Presiden pada Rapat Paripurna harus dihadiri oleh sekurang-kurangnya $2 / 3$ (dua pertiga) dari seluruh Anggota. Keputusan untuk menyetujui atau menolak pernyataan pendapat, harus didukung oleh sekurang-kurangnya 2/ 3 (dua pertiga) dari Anggota yang hadir dalam rapat tersebut ${ }^{16}$. Bila anggota DPR RI saat ini berjumlah 560 anggota, maka $2 / 3 \times 560=373,33$ dibulatkan menjadi 374 Anggota. Kourum kehadiran sidang paripurna juga sekurang-kurangnya harus $2 / 3$ dari jumlah anggota DPR (374 anggota).

Bila Keputusan Rapat Paripurna menyetujui usulan tuduhan impeachment tersebut maka pendapat tersebut disampaikan kepada MK untuk disidang. Apakah benar dakwaan DPR atau salah. Dalam sidang di MK prosesnya bisa cepat, bisa lambat. Tergantung pembuktian dari pihak DPR dan presiden. Tetapi waktunya dibatasi maksimal 90 hari harus putus. Jika dakwaan DPR diterima MK, maka DPR dapat melanjutkan dakwaan soal pemakzulan dengan menggelar sidang paripurna lagi untuk meminta agar MPR menggelar sidang istimewa. Namun, jika MK menolak dakwaan DPR, secara otomatis usulan pendakwaan akan gugur karena keputusan MK itu bersifat final dan mengikat.

Kalau MK menolak dakwaan DPR karena kurang bukti dan tidak kuat datanya, tidak ada usul dan prosesi pemakzulan. Tetapi kalau MK mengabulkan, babak baru politiknya dimulai lagi. MPR wajib menyelenggarakan sidang istimewa untuk memutus usul DPR tersebut paling lambat 30 (tiga puluh) hari sejak MPR menerima usul tersebut. Keputusan MPR atas usul pemberhentian Presiden dan/atau wakil presiden harus diambil dalam rapat paripurna MPR yang dihadiri oleh sekurang-kurangnya $3 / 4$ dari jumlah anggota $(3 / 4 \times 692=519)$ anggota dan disetujui sekurang-kurangya $2 / 3$ dari jumlah anggota yang hadir $(2 / 3 \times 519=346)$, setelah Presiden dan/atau wakil Presiden diberi kesempatan menyampaikan penjelasan dalam rapat paripurna MPR. Syarat $3 / 4$ itu untuk membuktikan bahwa memang pemakzulan itu penting sehingga harus dihadiri peserta sidang yang banyak, tidak hanya dihadiri nggota DPR tapi juga DPD agar keputusan yang diambil tidak bisa main-main. ${ }^{17}$

Ketua Mahkamah Konstitusi Mahfud MD menjelaskan, kehatihatian pengaturan soal pemakzulan ini didasarkan pada alasan agar DPR tidak mudah dan semena-mena menjatuhkan presiden. Setiap

16 Analisis Proses Impeachment Menurut Uud Negara Republik Indonesia Tahun 1945 (Setelah Perubahan)/Proses Impeachment Di DPR, http://id.wikisource.org/wiki.

17 Wapres Tidak Dikenal Non aktif, Ada Kemungkinan MPR Bersidang Kembali, http://www.mpr.go.id/index, 11 Desember 2009. 
proses pemakzulan harus melalui prosedur dan proses yang tidak mudah dan berliku. ${ }^{18}$

b. Sejarah Pemakzulan Presiden dan Wakil Presiden di Indonesia

Dalam sejarah ketatanegaraan di Indonesia, "pemakzulan" presiden di Indonesia pernah terjadi beberapa kali, yaitu:

1) Presiden pertama, Soekarno, dimakzulkan setelah menjadi presiden selama dua puluh tahun. Pemakzulan ini tidak sesuai dengan UUD 1945, meskipun MPR yang menurunkan secara resminya. Hal itu terjadi karena secara defacto Soeharto memegang kekuasaan negara. Pemakzulan ini dengan cara "kudeta lembut".

2) Presiden kedua, Soeharto dimakzulkan dengan paksaan halus juga setelah defacto rakyat tidak mendukungnya. Namun, Soeharto "tahu diri", dia memakzulkan dirinya sendiri. Itulah sebabnya beliau sangat cerdik dan "licin" sehingga lepas dari jerat untuk dibawa ke pengadilan.

3) Presiden keempat, "Gus Dur" yang secara demokratis dipilih oleh MPR dan dipilih dengan suara terbanyak, namun dimakzulkan juga oleh MPR. Menurut teori pemakzulan presiden di Indonesia itu harus memenuhi syarat: korupsi, berbuat maksiat, melanggar hukum, dan sejenisnya. Hal ini terjadi pada "Gus Dur" tanpa dipanggil terlebih dahulu untuk mempertanggungjawabkan perbuatannya dengan tiba-tiba MPR langsung memakzulkannya. Contoh "masa lalu" pemakzulan "Gus Dur" adalah contoh yang jelas-jelas terlihat oleh semua pihak bahwa bagaimana lidah para politisi dan negarawan saat itu memiliki "lidah tak bertulang". ${ }^{19}$

\section{PENUTUP}

Istilah pemakzulan tidak tertulis eksplisit dalam konstitusi. Dalam Kamus Besar Bahasa Indonesia Edisi Baru disebutkan makzul adalah meletakan jabatan; turun tahta raja. Prof. Jimly Asshiddiqie menjelaskan, pemakzulan adalah bahasa serapan dari bahasa Arab yang berarti diturunkan dari jabatan. Atau sama dengan istilah 'impeachment' dalam konstitusi negara-negara Barat. Pemberhentian Presiden dan/atau Wakil Presiden mekanismenya sudah diatur di dalam Pasal 7A dan 7B UUD 1945. Sebelum MPR memberhentikan baik itu Presiden dan/atau Wapres, mekanisme yang harus ditempuh terlebih dahulu adalah, usul pemberhentian Presiden dan/atau Wakil presiden tersebut diajukan oleh Dewan Perwakilan Rakyat (DPR) kepada MPR dengan hanya terlebih dahulu mengajukan permintaan kepada Mahkamah Konstitusi (MK) untuk memeriksa, mengadili, dan memutus pendapat DPR bahwa Presiden dan/atau Wakil Presiden telah melakukan pelanggaran hukum berupa pengkhianatan terhadap Negara, korupsi, penyuapan, tindak pidana berat

18 Mekanisme dan Prosedur Panjang Pemakzulan Presiden dan Wapres, op. cit.

19 Arifin Hendra Tanujaya, Antara Pemakzulan, UUD 1945, Peraturan MK, Pergantian Presiden-Wapres dan Kudeta, Kompas, 7 Februari 2010. 
lainnya, atau perbuatan tercela; dan/atau pendapat bahwa Presiden dan/atau wakil presiden tidak lagi memenuhi syarat sebagai presiden dan/atau wakil presiden.

\section{DAFTAR PUSTAKA}

\section{A. Buku}

Asshidiqie, Jimly, 2000, Konsolidasi Naskah UUD 1945 Setelah Perubahan Keempat, PSHTN FH-UI, Jakarta;

Budiardjo, Mirriam, 2001, Dasar-Dasar I/mu Politik, Cet. 20, PT. Gramedia Jakarta;

\section{B. Jurnal}

Muhammad Bahrul Ulum, Mekanisme Pemkazulan Presiden dan/atau Wakil Presiden Menurut Undang-Undang Dasar 1945 (Antara Realita Politik dan Penegakan Konstitusi), Jurnal Konstitusi, Volume 7, Nomor 4, 2016;

Ilham Imaman, Andri Kurniawan, Mekanisme Pemakzulan (Impeachment) Presiden dan/atau Wakil Presiden Oleh Majelis Permusyawaratan Rakyat Menurut Undang-Undang Negara Republik Indonesia Tahun 1945, Jurnal Ilmiah Mahasiswa Bidang Hukum Kenegaraan, Volume 1, Nomor 1, 2011;

Eko Noer Krisyanto, Pemakzulan Presiden Republik Indonesia Pasca Amandemen UUD 1945, Rechvinding, Volume 2 Nomor 2, Desember 2013;

M. Laica Marzuki, Pemakzulan Presiden/Wakil Presiden Menurut Undangundang Dasar 1945, Jurnal Konstitusi, Volume 7 Nomor 1, Februari 2010;

\section{Perundang-undangan}

Majelis Permusyawaratan Rakyat, Ketetapan MPR No. VI/MPR/2010 tentang Peraturan Tata Tertib MPR;

Peraturan Mahkamah Konstitusi Nomor 21 Tahun 2009;

Umdang-Undang Dasar Republik Indonesia Tahun 1945;

D. Internet

Pengamat : Wapres Bisa di Non Aktifkan, http://suaramerdeka.com. Sabtu, 23 Januari 2010;

Presiden : Wapres dan Menkeu Tidak Perlu Nonaktif, www.arsipberita.com/.../presiden-wapres-dan-menkeu-tidak-perlunonaktif, 20 Desember 2009;

SBY: Impeachment Harus Mengacu UUD 1945, www.republika.co.id/berita/101848/sby_kita_tak_menganut_mosi_ti dak_percaya;

Pemakzulan Presiden dan Wapres Dimungkinkan, 
http://www.detiknews.com/read/pemakzulan-presiden-dan-wapresdimungkinkan

Mekanisme dan Prosedur Panjang Pemakzulan Presiden dan Wapres, http://holistikasaya. wordpress.com/2010/01/31/mekanisme-danprosedur-panjang-pemakzulan-presiden-dan-wapres/;

Tak Ada Celah Pemakzulan Presiden dan Wapres, www.republika.co.id/ menkumham_tak_ada_celah_pamkzulan_presiden_dan_wapres, Selasa, 02 February 2010;

Skandal Bank Century: Pemakzulan Presiden Masih Jauh, http://www.mediaindonesia.com/read/ Pemakzulan-Presiden-MasihJauh, Sabtu, 23 Januari 2010;

Pemakzulan tidak dikenal dalam konstitusi, http://www.waspada.co.id/index;

Mekanisme dan Prosedur Panjang Pemakzulan Presiden dan Wapres, http://holistikasaya. wordpress.com/2010/01/31/mekanisme-danprosedur-panjang-pemakzulan-presiden-dan-wapres;

Analisis Proses Impeachment Menurut Uud Negara Republik Indonesia Tahun 1945 (Setelah Perubahan)/Proses Impeachment Di DPR, http://id.wikisource.org/wiki;

Wapres Tidak Dikenal Non aktif, Ada Kemungkinan MPR Bersidang Kembali, http://www.mpr.go.id/index. 